\title{
Growth of Knowledge of the Ionosphere
}

$I^{\mathrm{T}}$

is now well known that all long-distance radio communication takes place by the propagation of electric waves through the upper regions of the atmosphere which are embraced by the modern term 'ionosphere'. Although a conducting upper atmosphere was postulated in 1902, direct experimental evidence of its existence was not obtained until 1924. Since the latter date, a vast and increasing amount of research has been devoted to the ionosphere as a branch of theoretical and applied physics. While the major portion of this work has been conducted in Great Britain and in the United States, the fascination of the subject has attracted a number of research workers in other countries. The results of this work are generally recorded in the various scientific publications of the world. These publications are so numerous and so widespread, however, that the industrious worker in the subject is faced with a strenuous task if he is to study them all. Those whose main interest lies in other fields find it increasingly difficult to maintain an up-to-date knowledge on the ionosphere, and particularly to keep a clear perspective view of the progress which has been achieved and of its bearing on other fields such as meteorology and geophysics.

It is here that Prof. S. K. Mitra has come to our rescue with his "Report on the Present State of our Knowledge of the Ionosphere", which was prepared for the opening of a symposium organised by the National Institute of Sciences of India in 1935, and is now reprinted from the Prbceedings of that body. This report presents in a connected and concise form the main results of both theoretical and experimental investigations on the ionosphere during the past twelve years. The work has been treated from a funda. mental point of view, and it is not concerned with the science or practice of radio communication except in so far as radio methods are nowadays employed as a tool for the exploration of the upper atmosphere.
The first large section of the paper gives in a clear and concise manner the theory of the propagation of electric waves through an ionised gaseous medium, introducing in sequence the effects of the earth's magnetic field and of energy dissipation by collisions. The results of the theoretical treatment are illustrated by typical dispersion curves showing the effects of these quantities upon the refractive index and absorb. ing powers of the medium and on the polarisation of the transmitted waves.

Next, an outline is given of the three main experi. mental methods which have been developed for the study of the properties of the ionosphere. The two of these most widely used involve the emission of a radio signal with special characteristics impressed upon it, and the study of the echo signal upon its return from the ionosphere to earth. A description is given of the methods by which information is obtained, from such records, on the equivalent height of the ionosphere, and the density and gradient of ionisation. Indeed modern research based on a study of such records of received signals is providing us with a detailed knowledge of the structure of the atmosphere at heights above about $80 \mathrm{~km}$.; such knowledge is at present unobtainable in any other way. Throughout the paper, typical results of this research are presented in graphical form, and an appendix provides a bibliography, which has the merit of being obviously selected on a critical basis rather than of being entirely comprehensive.

Prof. Mitra appears to have succeeded admirably in compressing a large volume of matter into a small space, and in a subject which is progressing as rapidly as that under discussion, this has necessarily involved omitting reference to many investigations, which although helpful in the general progress of the work, are of lesser fundamental importance. The report should prove of great use to those studying or carrying out research in this most fascinating subject.

\section{Bacteriological Grading of Milk in Great Britain}

G RADING of milk was introduced in Great Britain in 1923. Producers who conformed to certain rules and attained certain standards for the milk they supplied were given the right to apply certain statutory names to their products. It was expected that both the public and the producers would benefit, the former by obtaining a more hygienic milk supply, the latter by an increased commercial return-hopes not altogether realised. After consideration and consultation respecting the working of the Order during the past seven years, the Minister of Health has decided to institute a new "Milk (Special Designations) Order, 1936", which came into operation on June 1.

The new Order has two main objects-to transfer from the Minister to local authorities the duty of granting licences to producers of certain graded milks, and to improve and simplify the special designations of milk. The present designations are 'Certified', 'Grade A. (Tuberculin Tested)', 'Grade A' and 'Pasteurised'. It is considered that so many grades create confusion, and the designations of some do not give a clear indication of their nature. Accord. ingly it is proposed to reduce the number of grades to three- 'Tuberculin 'Tested', 'Accredited' and 'Pasteurised'. 'Tuberculin Tested' is raw milk from tuberculin tested cows and will replace the existing designations 'Certified' and 'Grade A. (Tuberculin Tested)'; it may also be pasteurised. 'Accredited' milk will replace the present 'Grade A' milk, and like the latter will be raw milk from cows regularly inspected by a veterinary surgeon, but not tuberculin tested. 'Pasteurised' milk will, as at present, be milk which has been held at a temperature of $145^{\circ}-150^{\circ} \mathrm{F}$. 
for 30 minutes. The new Order contains a number of other provisions and administrative requirements for carrying it out. As it will affect large numbers of people, Sir Kingsley Wood has also issued an explanatory Memorandum setting out in non-technical language the effect of the Order and the way in which it will work ${ }^{2}$.

Bacteriological standards were prescribed for the various elasses of graded milk under the Order of 1923, namely, 'Certified' and 'Grade A. (Pasteurised)' must not contain more than 30,000 bacteria per c.c. and must not contain coliform bacilli in 1/10 c.c., 'Grade A. (Tuberculin Tested)' and 'Grade A' must not contain more than 200,000 bacteria per c.c. nor coliform bacilli in 1/100 c.c., and 'Pasteurised' must not contain more than 100,000 organisms per c.c., and the conditions for sampling and testing were standardised by the Ministry of Health so far as possible, so that it was hoped that reasonably concordant results might be obtained by different analysts. It was found in practice, however, that reputable workers employing a similar technique obtained the most discordant results, and a critical inquiry into the validity of the methods available for the bacteriological grading of milk was carried out for the Medical Research Council by Prof. G. S. Wilson and his assistants ${ }^{3}$. It was found that the plate count test for numbers of bacteria breaks down on account of the irregularity of distribution and clumping of the organisms in the milk, so that, under the best conditions, on any count an allowance of \pm 90 per cent may have to be made. Much the same may be said of the coliform test, except for pasteur. ised milk, when it may be of some value, serving as an index of the efficiency of the processing if performed with the freshly pasteurised milk. The new Order, therefore, while prescribing plate count tests for raw 'Tuberculin Tested' and 'Accredited' milks until December 31, 1936, substitutes for them a methylene blue reduction test for these milks on and after January 1, 1937. In addition, a coliform test is prescribed for these milks. Plate counts are to be continued for 'Tuberculin Tested Milk (Pasteurised)' and for 'Pasteurised' milk, the method of carrying out these tests being the same as obtains at present (Memo. 139/Foods). The methylene blue reduction test was the subject of much experimental work by Prof. Wilson and his colleagues, and appeared to fulfil most of the requirements demanded of a test for routine grading of raw milk. It is a simple test, with a very small experimental error, can be carried out by relatively unskilled workers on a large number of samples, and requires little equipment. By means of it, milk can be classified into the three or four grades necessary on the basis of cleanliness, it affords a useful index of the keeping qualities and gives more information about the milk than does the plate count. Allusion is also made to the possible use of the phosphatase test of Kay and Graham for the detection of imperfect pasteurisation.

1 Ministry of Health: Statutory Rules and Orders 1936. No 356. 4d. net. Circular 1533. 2d. net. (London: H.M. Stationery Office, 1936.)

Sale of Milk under Special Designations. Memo. 197/Foods. 3d. net.

3 Medical Research Council. Special Report Series, No. 206: The Bacteriological Grading of Milk. By $G$. S. Wilson, assisted by $R$. S. Bacteriological Grading of Milk. By G. S. Wilson, assisted by R. S.
Twigg, R. C. Wright, C. B. Hendry, M. P. Cowell and I. Maier. Pp. Twigg, R. C. Wright, C. B. Hendry, M. P. Cowell and I. Mai

\section{Transitional Cultures in the Stone Age}

A STUDY of the late palæolithic, mesolithic and early neolithic periods, of which the conclusions point to the necessity of a reclassification and further refinement in the definition of their characteristic industries, is based by M. Laurent Coulonges on his exploration of the prehistoric sites of Sauveterre-la. Lémance (Lot-et-Garonne). His report on his excavations and discussion of the evidence are published by the Institut de Paléontologie Humaine (Archives, Mém. 14).

Two sites were under investigation. They are situated on either side of the Paris-Agen railway in the valley of the Lémance, a tributary of the Lot, in the Canton of Fumel in the north-east of the department. One of the sites consists of two rock shelters on the south side of a detached island of the Cretaceous limestone, known as Le Martinet. They were first brought to light in 1868 when the railroad was under construction. M. Coulonges began excavation here in 1923. The second site, situated 300 metres away to the north, is a rock-shelter on the north side of the Roc Allan beside the Périgueux road.

Le Martinet. On this site ten different levels were clearly to be distinguished. Its importance lies in the fact that here, for the first time, was found on one and the same site a stratigraphic succession of Upper Palæolithic, Mesolithic and Neolithic. Of the various levels, the first was archæologically sterile, as was the third; the second level is Upper Palæolithic, the fourth, fifth and sixth, Mesolithic, the seventh, Neolithic, and the eighth, Iron Age and GalloRoman, with sub-soil and soil above.

In regard to cultures, that of Level 2 is Upper Magdalenian, but with certain resemblances to Azilian, more especially the Azilian of the Dordogne, and it is, therefore, here regarded as a proto-Azilian. In the Mesolithic three stages are differentiated. Level 4 contains a characteristic Azilian industry in demonstrable relations to palæolithic types; and sharply contrasting with them is a considerable number of microlithic implements in a great variety of types in pygmy form. For this industry the specific name of Sauveterrian is adopted. It is followed in Level 5 by what is obviously the industry of a new race, differing in its culture and habits from the Sauveterrian. There is, for example, for the first time in this station, the evidence of a hut site. This is Tardenois I, and unlike Sauveterrian which clearly represents a local development, it is an intrusive culture from outside. In this the most typical and characteristic implement is the trapezoidal barbpoint (pointe-barbelure). The industry is free from extraneous influence, a fact perhaps most patently indicated by the striking absence of the characteristic small triangular forms of the Sauveterrian.

The cultural break between Levels 4 and 5 is also marked in the fauna, the presence of the beaver and Helix nemoralis in quantity in Level 4 pointing to a period of humidity. 